\title{
Synthesis and characterization of xylene-based group-six metal PCP pincer complexes
}

\author{
Wolfgang Eder ${ }^{1} \cdot$ Berthold Stöger $^{2} \cdot$ Karl Kirchner $^{1}$ (1)
}

Received: 16 February 2019 / Accepted: 1 April 2019 / Published online: 10 June 2019

(c) The Author(s) 2019

\begin{abstract}
In the present study, the $\mathrm{Cr}(\mathrm{III})$ complex trans- $\left[\mathrm{Cr}\left(\mathrm{PCP}^{\mathrm{CH} 2}-i \mathrm{Pr}\right)\left(\mathrm{CH}_{3} \mathrm{CN}\right)(\mathrm{Br})_{2}\right]$ as well as seven-coordinate cationic bromo carbonyl Mo(II) and W(II) complexes of the type $\left[\mathrm{M}\left(\mathrm{PCP}^{\mathrm{CH}}{ }_{-}-\mathrm{Pr}\right)(\mathrm{CO})_{3} \mathrm{Br}\right](\mathrm{M}=\mathrm{Mo}, \mathrm{W})$ featuring PCP pincer ligands based on a xylene scaffold were prepared and characterized. The seven-coordinate bromo tricarbonyl complexes exhibit fluxional behavior in solution due to rapid CO ligand interconversions. The mechanism of this process was studied by means of DFT calculations. Structures of representative complexes were determined by single-crystal X-ray analyses.
\end{abstract}

\section{Graphical abstract}

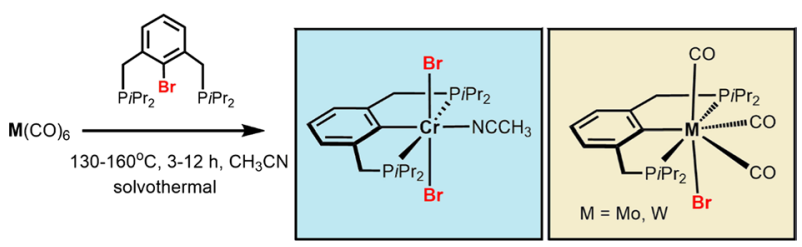

Keywords Chromium $\cdot$ Molybdenum $\cdot$ Tungsten $\cdot$ Pincer complexes $\cdot$ Carbonyl ligands $\cdot$ DFT calculations

\section{Introduction}

PCP pincer complexes which feature an aromatic anionic benzene backbone connected to phosphine donors via $\mathrm{CH}_{2}$, $\mathrm{O}$, or $\mathrm{NR}(\mathrm{R}=\mathrm{H}$, alkyl, aryl) linkers are a very attractive class of compounds [1-3]. With respect to group-six metals, PCP complexes are exceedingly rare [1]. In fact, according to our knowledge, there are only three established Mo and W systems, and one Cr system described as shown in Scheme 1

Electronic supplementary material The online version of this article (https://doi.org/10.1007/s00706-019-02422-6) contains supplementary material, which is available to authorized users.

Karl Kirchner

karl.kirchner@tuwien.ac.at

1 Institute of Applied Synthetic Chemistry, Vienna University of Technology, Getreidemarkt 9/163-AC, 1060 Vienna, Austria

2 X-ray Center, Vienna University of Technology, Getreidemarkt 9/163-OC, 1060 Vienna, Austria
[4-7]. Such complexes were shown to be promising candidates for the activation and splitting of small molecules such as dinitrogen. Schrock and co-workers discovered [4] that the $\mathrm{Mo}(\mathrm{III}) \mathrm{PCP}$ pincer complex $\left[\mathrm{Mo}(\mathrm{POCOP}-t \mathrm{Bu})(\mathrm{I})_{2}\right]$ forms upon reduction with $\mathrm{NaHg}$ in the presence of $\mathrm{N}_{2}$ the anionic $\mathrm{Mo}(\mathrm{IV})$ nitride complex $[\mathrm{Mo}(\mathrm{POCOP}-t \mathrm{Bu})(\mathrm{N})(\mathrm{I})]^{-}$.

Here we utilize the oxidative addition of the $\mathrm{C}-\mathrm{Br}$ bond of the ligand precursor (2-bromo-1,3-phenylene)bis(methylene) bis(diisopropylphosphane) $\left(\mathrm{P}(\mathrm{C}-\mathrm{Br}) \mathrm{P}^{\mathrm{CH} 2}-i \mathrm{Pr}\right)(\mathbf{1})$ to the hexacarbonyl complexes $\left[\mathrm{M}(\mathrm{CO})_{6}\right](\mathrm{M}=\mathrm{Cr}, \mathrm{Mo}, \mathrm{W})$ as synthetic entry into group-six metal PCP pincer complexes. This procedure has been successfully applied recently for the synthesis of several $\mathrm{Cr}, \mathrm{Mo}, \mathrm{W}, \mathrm{Mn}$, and Fe PCP complexes bearing $\mathrm{NR}(\mathrm{R}=$ alkyl $)$ linkers $[8,9]$. X-ray structures of the Mo and $\mathrm{W}$ complexes are presented. 
Scheme 1

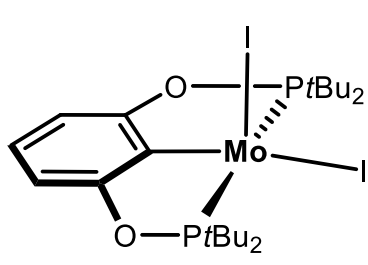

Schrock 2012

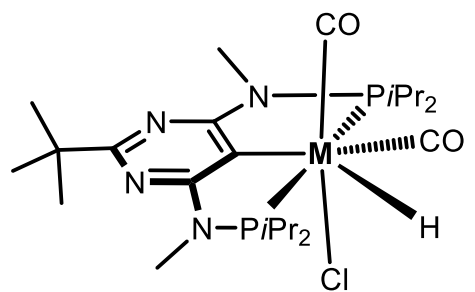

$M=M o, W$

Kirchner 2018
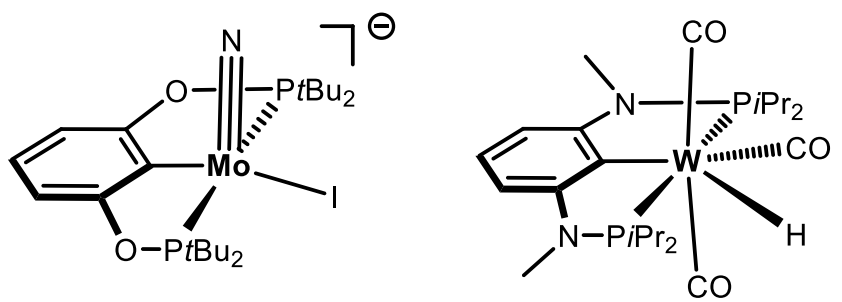

Kirchner 2016

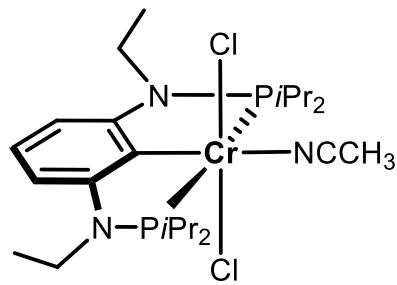

Kirchner 2018

\section{Results and discussion}

The xylene-based PCP ligand $\mathbf{1}$ was prepared in a two-step process following a literature procedure [10]. 2-Bromo-1,3bis(bromomethyl)benzene (1a) was treated with one equiv of $\mathrm{P} i \mathrm{Pr}_{2} \mathrm{H}$ to give the phosphonium intermediate $\mathbf{1 b}$ which was subsequently deprotonated with $\mathrm{NaOAc}$ in water to afford the desired ligand $\left(\mathrm{P}(\mathrm{C}-\mathrm{Br}) \mathrm{P}^{\mathrm{CH} 2}-i \mathrm{Pr}\right) \mathbf{1}$ in $49 \%$ isolated yield (Scheme 2).

A suspension of the hexacarbonyl complexes $\left[\mathrm{M}(\mathrm{CO})_{6}\right]$ $(\mathrm{M}=\mathrm{Cr}, \mathrm{Mo}, \mathrm{W})$ and one equivalent of $\mathrm{P}(\mathrm{C}-\mathrm{Br}) \mathrm{P}^{\mathrm{CH}}{ }_{-}-\mathrm{Pr}$ (1) in $\mathrm{CH}_{3} \mathrm{CN}$ was heated in a sealed microwave glass tube at $130{ }^{\circ} \mathrm{C}(\mathrm{Cr}), 130{ }^{\circ} \mathrm{C}(\mathrm{Mo})$ and $160{ }^{\circ} \mathrm{C}(\mathrm{W})$ for $3-12 \mathrm{~h}$. In the case of chromium, a mixture of several complexes was obtained. From this mixture, only the dibromo-Cr(III) complex with the tentative formula $\left[\mathrm{Cr}\left(\mathrm{PCP}^{\mathrm{CH} 2}-i \mathrm{Pr}\right)-\right.$ $\left.\left(\mathrm{CH}_{3} \mathrm{CN}\right)(\mathrm{Br})_{2}\right]$ (2) could be obtained in $40 \%$ isolated yield (Scheme 3). According to DFT calculations, the trans-bromide complex is more stable than the cis-isomer by $36.0 \mathrm{~kJ} /$ mol, which is in line with the fact that the analogous chloride compound, featuring NEt linkers, adopts a trans-chloride arrangement [7]. Due to the extreme air-sensitivity of this complex characterization was accomplished only by IR spectroscopy and magnetic measurements in solution. A solution magnetic moment of $\mu_{\text {eff }}=3.7 \mu_{\mathrm{B}}\left(\mathrm{CH}_{2} \mathrm{Cl}_{2}\right.$, Evans method) was determined which is consistent with three unpaired electrons as expected for a $\mathrm{d}^{3}$ configuration. In the IR, the $\nu_{\mathrm{CN}}$ stretching frequency of the acetonitrile ligand was observed at $2194 \mathrm{~cm}^{-1}$. The analogous compound bearing NEt linkers, exhibits the $\nu_{\mathrm{CN}}$ stretching frequency at $2207 \mathrm{~cm}^{-1}$ indicating that the xylene-based PCP pincer ligand is slightly more electron donating [7].

On the other hand, with molybdenum and tungsten the expected seven-coordinate bromo tricarbonyl Mo(II) and $\mathrm{W}(\mathrm{II})$ complexes $\left[\mathrm{Mo}\left(\mathrm{PCP}^{\mathrm{CH} 2}-i \mathrm{Pr}\right)(\mathrm{CO})_{3} \mathrm{Br}\right](3)$ and $\left[\mathrm{W}\left(\mathrm{PCP}^{\mathrm{CH} 2}-i \mathrm{Pr}\right)(\mathrm{CO})_{3} \mathrm{Br}\right](\mathbf{4})$ were obtained (Scheme 3$)$. These compounds were isolated in 80 and $83 \%$ yield and were characterized by ${ }^{1} \mathrm{H},{ }^{13} \mathrm{C}\left\{{ }^{1} \mathrm{H}\right\}$, and ${ }^{31} \mathrm{P}\left\{{ }^{1} \mathrm{H}\right\}$ NMR

Scheme 2

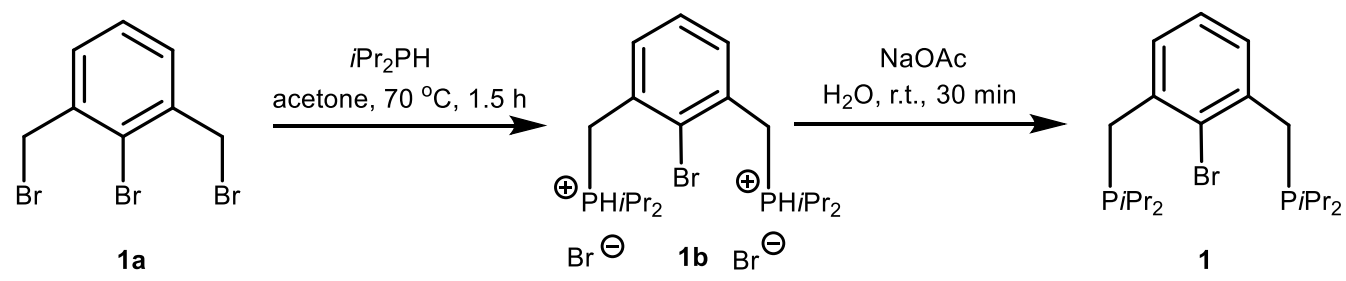


Scheme 3

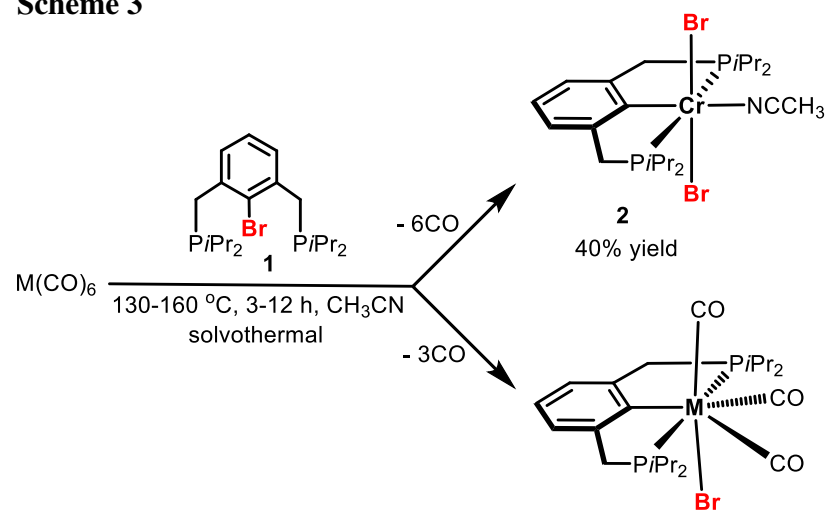

$M=M o(3) 80 \%$ yield $\mathrm{M}=\mathrm{W}(\mathbf{4}) 83 \%$ yield

spectroscopy, IR spectroscopy and HRMS. As typical for seven-coordinate complexes, $\mathbf{3}$ and $\mathbf{4}$ are fluxional in solution. Thus, in the ${ }^{31} \mathrm{P}\left\{{ }^{1} \mathrm{H}\right\}$ NMR spectra only one resonance is observed at 75.1 and 53.6 ppm, respectively. In the case of $\mathbf{4}$, the tungsten-phosphorus coupling was observed as a doublet satellite due to ${ }^{183} \mathrm{~W}$ (14\% natural abundance, $I=1 / 2$ ) which is superimposed over the dominant singlet $\left({ }^{1} J_{\mathrm{WP}}=84 \mathrm{~Hz}\right)$. Characteristic features comprise in the ${ }^{13} \mathrm{C}\left\{{ }^{1} \mathrm{H}\right\}$ NMR spectrum of 3 and 4 triplet resonances at $171.3 \mathrm{ppm}\left(J_{\mathrm{PC}}=8.0 \mathrm{~Hz}\right)$ and $168.9 \mathrm{ppm}$ $\left(J_{\mathrm{PC}}=6.8 \mathrm{~Hz}\right)$, respectively, assigned to the ipso carbon atoms of the benzene moiety. Moreover, the $\mathrm{CO}$ ligands give rise to one broad and one sharp low-field triplet resonance in a 2:1 ratio in the range of $238-218 \mathrm{ppm}$. The broad signals arise from a fast interchange process between two CO ligands (vide infra). In the IR spectra, they display the typical three strong $\nu_{\mathrm{CO}}$ bands at 2008 , 1923 , and $1871 \mathrm{~cm}^{-1}$ for 3 and $2000,1913,1859 \mathrm{~cm}^{-1}$ for 4. For comparison, the analogous complexes $\left[\mathrm{Mo}\left(\mathrm{PCP}^{\mathrm{NEt}}\right.\right.$ $\left.i \mathrm{Pr})(\mathrm{CO})_{3} \mathrm{Cl}\right]$ and $\left[\mathrm{W}\left(\mathrm{PCP}^{\mathrm{NEt}}-i \mathrm{Pr}\right)(\mathrm{CO})_{3} \mathrm{Cl}\right]$, featuring $\mathrm{NEt}$ linkers, display the three $\nu_{\mathrm{CO}}$ bands at 2007, 1921, and $1899 \mathrm{~cm}^{-1}$ and 2002,1915 , and $1878 \mathrm{~cm}^{-1}$, respectively, again indicating that the xylene-based pincer ligand is slightly more electron donating than the one based on the 1,3-diaminobenzene moiety [7].
The mechanism of the dynamic processes observed for the bromo carbonyl complexes $\mathbf{3}$ and $\mathbf{4}$ was investigated by means of DFT calculations (Fig. 1). The free energy profiles of these interconversions are depicted in Fig. 2. All CO ligands are involved in interchange (pseudorotation) processes that occur in single-step paths. The two $\mathrm{CO}$ ligands located closer to the PCP plane $\left(\mathrm{CO}^{1}\right.$ and $\left.\mathrm{CO}^{2}\right)$ exchange positions going through barriers of 53.3 and $57.4 \mathrm{~kJ} / \mathrm{mol}$ for Mo and $\mathrm{W}$, respectively. This reaction is the faster processes and corresponds to the one that could not be stopped in the NMR experiments even at $-50{ }^{\circ} \mathrm{C}$ (400 MHz). Exchanging the apical $\mathrm{CO}\left(\mathrm{CO}^{3}\right.$, trans to the bromide ligand) with one of the other two $\mathrm{CO}$ ligands is a considerably more difficult rearrangement. The calculated barriers, $96.4(\mathrm{M}=\mathrm{Mo})$ and $98.9 \mathrm{~kJ} / \mathrm{mol}(\mathrm{M}=\mathrm{W})$ are indicative of a process that should be slow under the experimental conditions. Therefore, the DFT calculations indicate that the apical $\mathrm{CO}\left(\mathrm{CO}^{3}\right)$ corresponds to the single signal in the ${ }^{13} \mathrm{C}\left\{{ }^{1} \mathrm{H}\right\}$ NMR spectrum, while the two $\mathrm{CO}$ ligands opposite to the PCP ligand and closer to its plane $\left(\mathrm{CO}^{1}\right.$ and $\left.\mathrm{CO}^{2}\right)$ are engaged in a fast exchange process and give rise to the broad ${ }^{13} \mathrm{C}\left\{{ }^{1} \mathrm{H}\right\}$ NMR signals associated with two of those ligands.

The solid-state structures of $\left[\mathrm{Mo}\left(\mathrm{PCP}^{\mathrm{CH} 2}-i \mathrm{Pr}\right)(\mathrm{CO})_{3} \mathrm{Br}\right]$ (3) and $\left[\mathrm{W}\left(\mathrm{PCP}^{\mathrm{CH} 2}-i \mathrm{Pr}\right)(\mathrm{CO})_{3} \mathrm{Br}\right](4)$ were determined by $\mathrm{X}$-ray diffraction. Molecular views of $\mathbf{3}$ and $\mathbf{4}$ are depicted in Figs. 3 and 4 and selected bond lengths and angles are provided in the captions. Complexes $\mathbf{3}$ and $\mathbf{4}$ are sevencoordinate species where the tridentate PCP ligand is bound in the typical meridional coordination mode and three carbonyls ligands and one bromide ligand are filling the remaining four sites.

\section{Conclusion}

In sum, we have prepared xylene-based group-six PCP metal complexes via a solvothermal approach starting from $\left[\mathrm{M}(\mathrm{CO})_{6}\right](\mathrm{M}=\mathrm{Cr}, \mathrm{Mo}, \mathrm{W})$ and (2-bromo-1,3-phenylene) bis(methylene)bis(diisopropylphosphane) $\left(\mathrm{P}(\mathrm{C}-\mathrm{Br}) \mathrm{P}^{\mathrm{CH}}{ }_{-}\right.$ $i \mathrm{Pr})$. Treatment of $\left[\mathrm{Cr}(\mathrm{CO})_{6}\right]$ with $\mathrm{P}(\mathrm{C}-\mathrm{Br}) \mathrm{P}^{\mathrm{CH} 2}-i \mathrm{Pr}$ in

Fig. 1 Calculated structures of trans- and cis- $\left[\mathrm{Cr}\left(\mathrm{PCP}^{\mathrm{CH} 2}{ }_{-i \mathrm{Pr}}\right)\right.$ $\left.\left(\mathrm{CH}_{3} \mathrm{CN}\right)(\mathrm{Br})_{2}\right]$
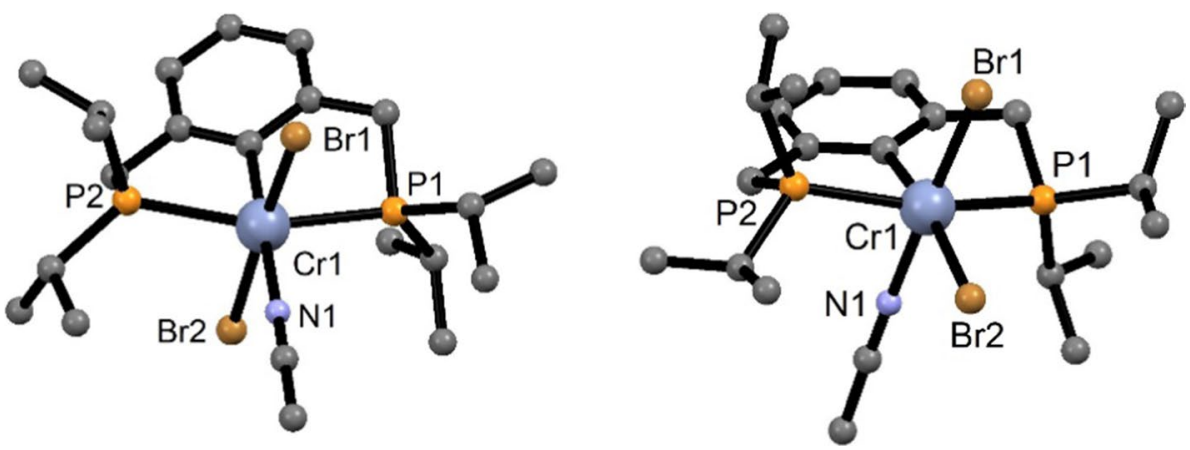
Fig. 2 Free-energy profile (kJ/ $\mathrm{mol}$ ) for the "pseudorotations" of the CO ligands in $\mathbf{3}$ and $\mathbf{4}$

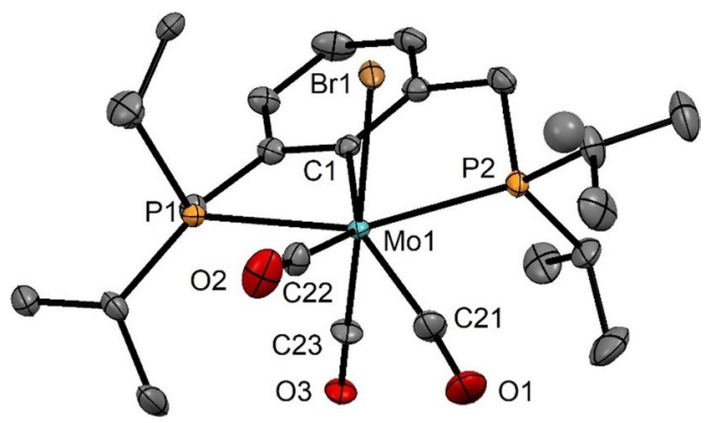

Fig. 3 Structural view of $\left[\mathrm{Mo}\left(\mathrm{PCP}^{\mathrm{CH} 2}-\mathrm{Pr}\right)(\mathrm{CO})_{3} \mathrm{Br}\right]$ (3) with $50 \%$ thermal ellipsoids ( $\mathrm{H}$ atoms omitted for clarity). Selected bond lengths $(\AA)$ and bond angles $\left({ }^{\circ}\right)$ : Mo1-C1 2.286(4), Mo1-C21 1.987(6), Mo1-C22 2.023(6), Mo1-C23 1.952(8), Mo1-Br1 2.697(1), Mo1-P1 2.524(1), Mo1-P2 2.523(1), P1-Mo1-P2 147.84(4)

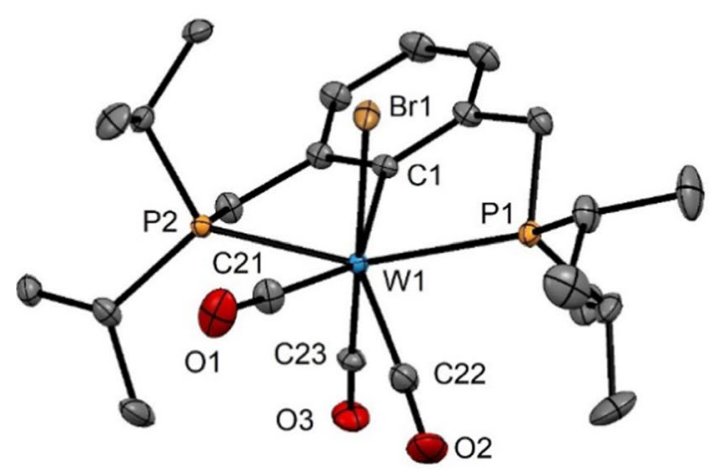

Fig. 4 Structural views of $\left[\mathrm{W}\left(\mathrm{PCP}^{\mathrm{CH} 2}-i \mathrm{Pr}\right)(\mathrm{CO})_{3} \mathrm{Br}\right](4)$ with $50 \%$ thermal ellipsoids ( $\mathrm{H}$ atoms omitted for clarity). Selected bond lengths $(\AA)$ and bond angles $\left({ }^{\circ}\right)$ : W1-C1 2.271(3), W1-C21 2.016(4),
$\mathrm{CH}_{3} \mathrm{CN}$ under solvothermal conditions resulted in the formation of the $\mathrm{Cr}$ (III) complex trans- $\left[\mathrm{Cr}\left(\mathrm{PCP}^{\mathrm{CH} 2}-i \mathrm{Pr}\right)\left(\mathrm{CH}_{3} \mathrm{CN}\right)-\right.$ $\left.(\mathrm{Br})_{2}\right]$ together with several unidentified compounds. In contrast, with $\left[\mathrm{M}(\mathrm{CO})_{6}\right](\mathrm{M}=\mathrm{Mo}, \mathrm{W})$ seven-coordinate cationic bromo carbonyl $\mathrm{Mo}(\mathrm{II})$ and $\mathrm{W}(\mathrm{II})$ complexes of the type $\left[\mathrm{M}\left(\mathrm{PCP}^{\mathrm{CH}}{ }_{-}-\mathrm{Pr}\right)(\mathrm{CO})_{3} \mathrm{Br}\right]$ were formed in high isolated yields. These seven-coordinate complexes are fluxional in solution due to $\mathrm{CO}$ interconversions. The mechanism of this dynamic behavior was studied by means of DFT calculations. All CO ligands are involved in pseudorotation processes that occur in single-step paths. The structures of the Mo and $\mathrm{W}$ complexes could be determined by single-crystal $\mathrm{X}$-ray analysis.

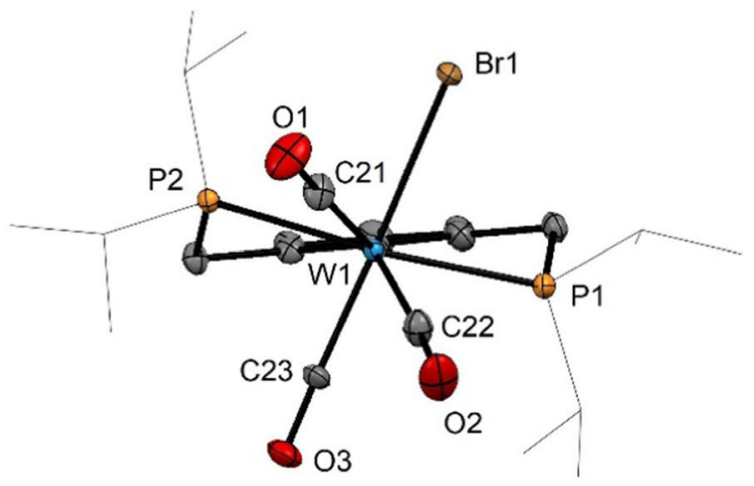

W1-C22 1.991(3), W1-C23 1.964(5), W1-Br1 2.6871(7), W1-P2 2.5219(7), W1-P1 2.5236(7), P1-W1-P2 148.42(2) 


\section{Experimental}

All manipulations were performed under an inert atmosphere of argon by using Schlenk techniques or in an MBraun inert-gas glovebox. The solvents were purified according to standard procedures [11]. Deuterated solvents were dried over $4 \AA$ molecular sieves. The synthesis of (2-bromo1,3-phenylene)bis(methylene)bis(diisopropylphosphane) $\left(\mathrm{P}(\mathrm{C}-\mathrm{Br}) \mathrm{P}^{\mathrm{CH}}{ }_{-}-\mathrm{Pr}\right)(\mathbf{1})$ was carried according to the literature [8]. ${ }^{1} \mathrm{H},{ }^{13} \mathrm{C}\left\{{ }^{1} \mathrm{H}\right\}$, and ${ }^{31} \mathrm{P}\left\{{ }^{1} \mathrm{H}\right\}$ NMR spectra were recorded on Bruker AVANCE-250 and 400 spectrometers. ${ }^{1} \mathrm{H}$ and ${ }^{13} \mathrm{C}\left\{{ }^{1} \mathrm{H}\right\}$ NMR spectra were referenced internally to residual protio-solvent, and solvent resonances, respectively, and are reported relative to tetramethylsilane $(\delta=0 \mathrm{ppm}) .{ }^{31} \mathrm{P}\left\{{ }^{1} \mathrm{H}\right\}$ NMR spectra were referenced externally to $\mathrm{H}_{3} \mathrm{PO}_{4}(85 \%)$ $(\delta=0)$. Room temperature solution $\left(\mathrm{CH}_{2} \mathrm{Cl}_{2}\right)$ magnetic moments were determined by ${ }^{1} \mathrm{H}$ NMR spectroscopy using the method of Evans [12].

High-resolution accurate mass data mass spectra were recorded on a hybrid Maxis Qq-aoTOF mass spectrometer (Bruker Daltonics, Bremen, Germany) fitted with an ESI source. Measured accurate mass data of the $[\mathrm{M}]^{+}$ions for confirming calculated elemental compositions were typically within $\pm 5 \mathrm{ppm}$ accuracy. The mass calibration was done with a commercial mixture of perfluorinated trialkyltriazines (ES Tuning Mix, Agilent Technologies, Santa Clara, CA, USA).

[(Dibromo)[2,6-bis[[bis(1-methylethyl)phosphino-kP]methyl]phenyl-KC] (acetonitrile)chromium(III)], $\left[\mathrm{Cr}\left(\mathrm{PCP}{ }^{\mathrm{CH} 2}{ }_{-} \mathrm{Pr}\right)\left(\mathrm{CH}_{3} \mathrm{CN}\right)(\mathrm{Br})_{2}\right]\left(2, \mathrm{C}_{22} \mathrm{H}_{38} \mathrm{Br}_{2} \mathrm{CrNP}_{2}\right)$ A suspension of $53 \mathrm{mg}\left[\mathrm{Cr}(\mathrm{CO})_{6}\right](0.24 \mathrm{mmol})$ and $100 \mathrm{mg} 1$ $(0.24 \mathrm{mmol})$ in $2.5 \mathrm{~cm}^{3}$ acetonitrile in a sealed microwave tube was heated at $130{ }^{\circ} \mathrm{C}$ for $12 \mathrm{~h}$ affording an orange solution. After evaporation of the solvent the remaining solid was washed three times with $n$-pentane $\left(10 \mathrm{~cm}^{3}\right)$. The residue was then taken up in $3 \mathrm{~cm}^{3}$ dichloromethane and precipitated with $10 \mathrm{~cm}^{3} n$-pentane giving 2 as reddish-brown solid. Yield: $45 \mathrm{mg}$ (40\%); $\mu_{\text {eff }}=3.7 \mu_{\mathrm{B}}$ (Evans method, $\mathrm{CH}_{2} \mathrm{Cl}_{2}$ ); IR (ATR): $=2194\left(\nu_{\mathrm{CN}}\right) \mathrm{cm}^{-1}$.

[(Bromo)[2,6-bis[[bis(1-methylethyl)phosphino-kP]methyl]phenyl- $\mathrm{KC}$ ](tricarbonyl)molybdenum(II)], [Mo( $\left.\mathrm{PCP}{ }^{\mathrm{CH} 2}-i \mathrm{Pr}\right)$ $\left.(\mathrm{CO})_{3} \mathrm{Br}\right]\left(3, \mathrm{C}_{23} \mathrm{H}_{35} \mathrm{BrMoO}_{3} \mathrm{P}_{2}\right)$ A suspension of $100 \mathrm{mg} 1$ $(0.24 \mathrm{mmol})$ and $63.2 \mathrm{mg}\left[\mathrm{Mo}(\mathrm{CO})_{6}\right](0.24 \mathrm{mmol})$ in $2.5 \mathrm{~cm}^{3}$ acetonitrile in a sealed microwave vial was heated at $130{ }^{\circ} \mathrm{C}$ for $3 \mathrm{~h}$ affording a red-brown solution. After cooling to room temperature orange-brown crystals precipitated from the mother liquor. The supernatant solution was decanted and the crystals were washed twice with $\mathrm{MeOH}\left(1 \mathrm{~cm}^{3}\right)$ to yield analytically pure 3 . Yield: $115 \mathrm{mg}(80 \%)$ as orange crystals. ${ }^{1} \mathrm{H}$ NMR $\left(400 \mathrm{MHz}, \mathrm{CD}_{2} \mathrm{Cl}_{2}, 20{ }^{\circ} \mathrm{C}\right.$ ): $\delta=7.13$ (d,
$\left.J=7.4 \mathrm{~Hz}, 2 \mathrm{H}, \mathrm{C}_{\mathrm{ar}} H\right), 6.99\left(\mathrm{t}, J=7.4 \mathrm{~Hz}, 1 \mathrm{H}, \mathrm{C}_{\mathrm{ar}} H\right), 4.04$ $\left(\mathrm{dt}, J=15.5 \mathrm{~Hz}, 5.0 \mathrm{~Hz}, 2 \mathrm{H}, \mathrm{CH}_{2} \mathrm{P}\right), 3.72(\mathrm{dt}, J=15.5 \mathrm{~Hz}$, $\left.3.9 \mathrm{~Hz}, 2 \mathrm{H}, \mathrm{CH}_{2} \mathrm{P}\right), 2.91\left(\mathrm{~m}, 2 \mathrm{H}, \mathrm{PCH}\left(\mathrm{CH}_{3}\right)_{2}\right), 2.47(\mathrm{~m}$, $\left.2 \mathrm{H}, \mathrm{PCH}\left(\mathrm{CH}_{3}\right)_{2}\right), 1.32\left(\mathrm{~m}, 18 \mathrm{H}, \mathrm{PCH}\left(\mathrm{CH}_{3}\right)_{2}\right), 1.10(\mathrm{~m}$, $\left.6 \mathrm{H}, \mathrm{PCH}\left(\mathrm{CH}_{3}\right)_{2}\right) \mathrm{ppm} ;{ }^{13} \mathrm{C}\left\{{ }^{1} \mathrm{H}\right\}$ NMR $\left(101 \mathrm{MHz}, \mathrm{CD}_{2} \mathrm{Cl}_{2}\right.$, $\left.20^{\circ} \mathrm{C}\right): \delta=238.1(\mathrm{br}, C \mathrm{C}), 224.5(\mathrm{t}, J=12.0 \mathrm{~Hz}, C \mathrm{O}), 171.3$ (t, $J=8.0 \mathrm{~Hz}$, Mo- $C$ ) $149.1\left(\mathrm{t}, J=7.8 \mathrm{~Hz}, C_{\mathrm{ar}} \mathrm{C}\right), 127.4$ $\left(C_{\mathrm{ar}} \mathrm{H}\right), 123.1\left(\mathrm{t}, J=8.0 \mathrm{~Hz}, C_{\mathrm{ar}} \mathrm{H}\right), 40.6\left(\mathrm{vt}, C_{2} \mathrm{P}\right), 27.6(\mathrm{t}$, $\left.J=9.5 \mathrm{~Hz}, \mathrm{PCH}\left(\mathrm{CH}_{3}\right)_{2}\right), 27.2\left(\mathrm{t}, J=10.4 \mathrm{~Hz},-\mathrm{PCH}\left(\mathrm{CH}_{3}\right)_{2}\right)$, $19.7\left(\mathrm{~m}, \mathrm{PCH}\left(\mathrm{CH}_{3}\right)_{2}\right) \mathrm{ppm} ;{ }^{31} \mathrm{P}\left\{{ }^{1} \mathrm{H}\right\}$ NMR $(162 \mathrm{MHz}$, $\left.\mathrm{CD}_{2} \mathrm{Cl}_{2}, 20^{\circ} \mathrm{C}\right): \delta=75.1 \mathrm{ppm}$; IR (ATR): $=2008\left(\nu_{\mathrm{CO}}\right), 1923$ $\left(\nu_{\mathrm{CO}}\right), 1871\left(\nu_{\mathrm{CO}}\right) \mathrm{cm}^{-1} ; \mathrm{HRMS}\left(\mathrm{ESI}^{+}, \mathrm{CH}_{3} \mathrm{CN} / \mathrm{MeOH}+1 \%\right.$ $\left.\mathrm{H}_{2} \mathrm{O}\right): \mathrm{m} / z$ calcd for $\left.\mathrm{C}_{23} \mathrm{H}_{35} \mathrm{O}_{3} \mathrm{BrNaMoP}_{2}(\mathrm{M}+\mathrm{Na}]^{+}\right)$ 621.0197, found 621.0181.

[(Bromo)[2,6-bis[[bis(1-methylethyl)phosphino-kP]methyl]phenyl-kC](tricarbonyl)tungsten(II)], [W( $\left.\left.\mathrm{PCP}{ }^{\mathrm{CH}}{ }_{-}-\mathrm{Pr}\right)(\mathrm{CO})_{3} \mathrm{Br}\right]$ $\left(4, \mathrm{C}_{23} \mathrm{H}_{35} \mathrm{BrO}_{3} \mathrm{P}_{2} \mathrm{~W}\right)$ This complex was prepared analogously to 3 with $84.4 \mathrm{mg}$ [W(CO) $)_{6}$ ] $(0.24 \mathrm{mmol})$ and $100 \mathrm{mg} 1$ $(0.24 \mathrm{mmol})$ as starting materials at $160{ }^{\circ} \mathrm{C}$. Yield: $136 \mathrm{mg}$ (83\%) as yellowish-brown crystals. ${ }^{1} \mathrm{H}$ NMR $(400 \mathrm{MHz}$, $\left.\mathrm{CD}_{2} \mathrm{Cl}_{2}, 20^{\circ} \mathrm{C}\right): \delta=7.16\left(\mathrm{~d}, J=7.5 \mathrm{~Hz}, 2 \mathrm{H}, \mathrm{C}_{\mathrm{ar}} H\right), 7.02(\mathrm{t}$, $\left.J=7.5 \mathrm{~Hz}, 1 \mathrm{H}, \mathrm{C}_{\mathrm{ar}} H\right), 4.10(\mathrm{dt}, J=15.6 \mathrm{~Hz}, 4.8 \mathrm{~Hz}, 2 \mathrm{H}$, $\left.\mathrm{CH}_{2} \mathrm{P}\right), 3.74\left(\mathrm{dt}, J=15.5 \mathrm{~Hz}, 3.9 \mathrm{~Hz}, 2 \mathrm{H}, \mathrm{CH}_{2} \mathrm{P}\right), 2.95(\mathrm{~m}$, $\left.2 \mathrm{H}, \mathrm{PCH}\left(\mathrm{CH}_{3}\right)_{2}\right), 2.51\left(\mathrm{~m}, 2 \mathrm{H}, \mathrm{PCH}\left(\mathrm{CH}_{3}\right)_{2}\right), 1.31(\mathrm{~m}, 18 \mathrm{H}$, $\left.\mathrm{PCH}\left(\mathrm{CH}_{3}\right)_{2}\right), 1.11\left(\mathrm{~m}, 6 \mathrm{H}, \mathrm{PCH}\left(\mathrm{CH}_{3}\right)_{2}\right) \mathrm{ppm} ;{ }^{13} \mathrm{C}\left\{{ }^{1} \mathrm{H}\right\}$ NMR (101 MHz, $\mathrm{CD}_{2} \mathrm{Cl}_{2}, 20^{\circ} \mathrm{C}$ ): $\delta=232.2$ (br, $C \mathrm{O}$ ), 217.5 $\left(\mathrm{t}, J=9.15 \mathrm{~Hz}, J_{\mathrm{wC}}=73 \mathrm{~Hz}, C O\right), 168.9(\mathrm{t}, J=6.80 \mathrm{~Hz}$, W-C), $150.7\left(\mathrm{t}, J=7.74 \mathrm{~Hz}, C_{\mathrm{ar}} \mathrm{C}\right), 127.6\left(C_{\mathrm{ar}} \mathrm{H}\right), 123.1(\mathrm{t}$, $\left.J=7.42 \mathrm{~Hz}, C_{\mathrm{ar}} \mathrm{H}\right), 40.8\left(\mathrm{vt}, \mathrm{CH}_{2} \mathrm{P}\right), 27.8\left(\mathrm{vt}, \mathrm{PCH}\left(\mathrm{CH}_{3}\right)_{2}\right)$, 26.8 (vt, $\left.\mathrm{PCH}\left(\mathrm{CH}_{3}\right)_{2}\right), 19.8\left(\mathrm{~m}, \mathrm{PCH}\left(\mathrm{CH}_{3}\right)_{2}\right) \mathrm{ppm} ;{ }^{31} \mathrm{P}\left\{{ }^{1} \mathrm{H}\right\}$ NMR (162 MHz, $\left.\mathrm{CD}_{2} \mathrm{Cl}_{2}, 20{ }^{\circ} \mathrm{C}\right): \delta=53.6\left({ }^{1} J_{\mathrm{WP}}=84 \mathrm{~Hz}\right)$ ppm; IR (ATR): $=2000\left(\nu_{\mathrm{CO}}\right), 1913\left(\nu_{\mathrm{CO}}\right), 1859\left(\nu_{\mathrm{CO}}\right) \mathrm{cm}^{-1}$; HRMS (ESI ${ }^{+}, \mathrm{CH}_{3} \mathrm{CN} / \mathrm{MeOH}+1 \% \mathrm{H}_{2} \mathrm{O}$ ): $\mathrm{m} / z$ calcd for $\mathrm{C}_{23} \mathrm{H}_{35} \mathrm{O}_{3} \mathrm{BrNaP}_{2} \mathrm{~W}\left([\mathrm{M}+\mathrm{Na}]^{+}\right)$707.0652, found 707.0620.

\section{X-ray structure determination}

X-ray diffraction data of $\mathbf{3}$ and 4 (CCDC 1897494 and $1897495)$ were collected at $T=100 \mathrm{~K}$ in a dry stream of nitrogen on a Bruker Kappa APEX II diffractometer system using graphite-monochromatized Mo- $K \alpha$ radiation $(\lambda=0.71073 \AA)$ and fine-sliced $\varphi$ - and $\omega$-scans. Data were reduced to intensity values with SAINT and an absorption correction was applied with the multi-scan approach implemented in SADABS [13]. The structure was solved by the dual-space approach implemented in SHELXT [14] and refined against $F^{2}$ with SHELXL [15]. Non-hydrogen atoms were refined anisotropically. The $\mathrm{H}$ atoms were placed in calculated positions and thereafter refined as riding on the parent atoms. The $\mathrm{Br}$ and $\mathrm{CO}$ ligands were refined as disordered about all four positions. The total occupancy of 
the $\mathrm{Br}$ atom was restrained to one. Molecular graphics were generated with the program MERCURY [16].

\section{Computational details}

Calculations were performed using the GAUSSIAN 09 software package [17] with the OPBE and PBE0 functionals without symmetry constraints, the Stuttgart/Dresden ECP (SDD) basis set to describe the electrons of the chromium, molybdenum and tungsten atoms and a standard $6-31 \mathrm{G}^{* *}$ basis for all other atoms as already described previously [7, 18].

Acknowledgements Open access funding provided by Austrian Science Fund (FWF). Financial support by the Austrian Science Fund (FWF) is gratefully acknowledged (Project no. P29584-N28). The $\mathrm{X}$-ray center of the Vienna University of Technology is acknowledged for financial support and for providing access to the single-crystal diffractometer.

Open Access This article is distributed under the terms of the Creative Commons Attribution 4.0 International License (http://creativecommons.org/licenses/by/4.0/), which permits unrestricted use, distribution, and reproduction in any medium, provided you give appropriate credit to the original author(s) and the source, provide a link to the Creative Commons license, and indicate if changes were made.

\section{References}

1. Murugesan S, Kirchner K (2016) Dalton Trans 45:4163

2. Albrecht M, van Koten G (2001) Angew Chem Int Ed 40:3750

3. van der Boom ME, Milstein D (2003) Chem Rev 103:1759

4. Hebden TJ, Schrock RR, Takase MK, Müller P (2012) Chem Commun 48:1851

5. de Aguiar SRMM, Stöger B, Pittenauer E, Allmaier G, Veiros LF, Kirchner K (2016) Organometallics 35:3032
6. Tomsu G, Mastalir M, Stöger B, Pittenauer E, Allmaier G, Kirchner K (2018) Organometallics 37:1919

7. Himmelbauer D, Mastalir M, Stöger B, Veiros LF, Kirchner K (2018) Organometallics 37:3631

8. Himmelbauer D, Mastalir M, Stöger B, Pignitter M, Somoza V, Veiros LF, Kirchner K (2018) Inorg Chem 57:7925

9. Himmelbauer D, Stöger B, Veiros LF, Kirchner K (2018) Organometallics 37:3475

10. Rybtchinski B, Ben-David Y, Milstein D (1997) Organometallics 16:3786

11. Perrin DD, Armarego WLF (1988) Purification of Laboratory Chemicals, 3rd edn. Pergamon, New York

12. Sur SK (1989) J Magn Reson 82:169

13. Bruker computer programs (2018) APEX2, SAINT, SADABS, and TWINABS. Bruker AXS Inc, Madison

14. Sheldrick GM (2015) Acta Crystallogr A 71:3

15. Sheldrick GM (2015) Acta Crystallogr C 71:3

16. Macrae CF, Edgington PR, McCabe P, Pidcock E, Shields GP, Taylor R, Towler M, van de Streek J (2006) J Appl Cryst 39:453

17. Frisch MJ, Trucks GW, Schlegel HB, Scuseria GE, Robb MA, Cheeseman JR, Scalmani G, Barone V, Mennucci B, Petersson GA, Nakatsuji H, Caricato M, Li X, Hratchian HP, Izmaylov AF, Bloino J, Zheng G, Sonnenberg JL, Hada M, Ehara M, Toyota K, Fukuda R, Hasegawa J, Ishida M, Nakajima T, Honda Y, Kitao $\mathrm{O}$, Nakai H, Vreven T, Montgomery JA Jr, Peralta JE, Ogliaro F, Bearpark M, Heyd JJ, Brothers E, Kudin KN, Staroverov VN, Kobayashi R, Normand J, Raghavachari K, Rendell A, Burant JC, Iyengar SS, Tomasi J, Cossi M, Rega N, Millam JM, Klene M, Knox JE, Cross JB, Bakken V, Adamo C, Jaramillo J, Gomperts R, Stratmann RE, Yazyev O, Austin AJ, Cammi R, Pomelli C, Ochterski JW, Martin RL, Morokuma K, Zakrzewski VG, Voth GA, Salvador P, Dannenberg JJ, Dapprich S, Daniels AD, Farkas Ö, Foresman JB, Ortiz JV, Cioslowski J, Fox DJ (2009) Gaussian 09, revision A.02. Gaussian Inc, Wallingford

18. Schröder-Holzhacker C, Stöger B, Pittenauer E, Allmaier G, Veiros LF, Kirchner K (2016) Monatsh Chem 147:1539

Publisher's Note Springer Nature remains neutral with regard to jurisdictional claims in published maps and institutional affiliations. 